\title{
Investigation of Adhesion and Tribological Behavior of Borided AISI 310 Stainless Steel
}

Ibrahim Gunes ${ }^{1}$, Ismail Y1ldiz ${ }^{2}$

\author{
${ }^{1}$ Metallurgical and Materials Engineering, Technology Faculty, Afyon Kocatepe University, 03200, Afyonkarahisar, \\ Turkey \\ e-mail: igunes@aku.edu.tr \\ ${ }^{2}$ Department of Machine Education, Iscehisar Vocational Schools, Afyon Kocatepe University, 03200, Afyonkarahisar, \\ Turkey; E-Mail: iyildiz@aku.edu.tr
}

\begin{abstract}
In the present study, the effects of the boriding process on adhesion and tribological properties of AISI 310 steel were investigated. Boriding was performed in a solid medium consisting of Ekabor-II powders at 1123 and $1323 \mathrm{~K}$ for 2 and $6 \mathrm{~h}$. The boride layer was characterized by optical microscopy, the X-ray diffraction technique and the micro-Vickers hardness tester. The X-ray diffraction analysis of the boride layers on the surface of the steels revealed the existence of $\mathrm{Fe}_{\mathrm{x}} \mathrm{B}_{\mathrm{y}}, \mathrm{Cr}_{\mathrm{x}} \mathrm{B}_{\mathrm{y}}$ and $\mathrm{Ni}_{\mathrm{x}} \mathrm{B}_{\mathrm{y}}$ compounds. Depending on the chemical composition of substrates, the boride layer thickness on the surface of the AISI 310 steel was found to be $56.74 \mu \mathrm{m}$. The hardness of the boride compounds formed on the surface of the AISI 310 steel ranged from 1658 to $2284 \mathrm{HV}_{0,1}$, whereas the Vickers hardness value of the untreated steel AISI 310 was $276 \mathrm{HV}_{0,1}$. The wear tests were carried out in a ball-disc arrangement under a dry friction condition at room temperature with an applied load of $10 \mathrm{~N}$ and with a sliding speed of $0.3 \mathrm{~m} / \mathrm{s}$, at a sliding distance of $1000 \mathrm{~m}$. The wear surfaces of the steel were analyzed using an SEM microscopy and X-ray energy dispersive spectroscopy EDS. It was observed that the wear rate of unborided and borided AISI 310 steel ranged from 4.57 to $71.42 \mathrm{~mm}^{3} / \mathrm{Nm}$.
\end{abstract}

Keywords: AISI 310, Boriding, Micro-Hardness, Adhesion, Tribology.

\section{INTRODUÇÃO}

Boriding is a thermochemical surface hardening process which occurs with the diffusion of boron atoms on the matrix surface. The introduced boron atoms react with the material and form a number of borides. As a result of these formations, boronizing of the surface of a material allows a significant reduction of the rate of corrosion, oxidation or shaping of fatigue cracks that occur as an outcome of its operation [1-4]. But the main advantage of boronizing metals is the possibility to alloy a high surface hardness with a low friction coefficient. This may lead to good wear resistance. The increase in hardness due to boronizing of steels resulted in decreased wear rates in [5].

The wear and friction behaviors of borided steels are broadly dependent on the following surface and boriding conditions: boriding time and temperature, chemical composition, mechanical properties, physical structure, lubricant, surface roughness, etc. As result of these conditions, the life of machine components may be affected. The efficiency, durability and reliability are improved by reducing friction and wear rate via certain materials, surface modifications and lubricants [6-8].The need to overcome wear is an old and well recognized problem that presents a unique challenge to the designer and the developer of steel components for many engineering applications, for example in crushing mills, sieves, shaft pins, skip hoist elements, conveyors, blades, gear and sprocket wheels, self-dumping cars elements, loading machines, trucks, front casting bulldozers, buckets and worm transporters. The borided steel surfaces with a high hardness have outstanding wear resistance. Therefore, boriding are common thermochemical surface treatments applied to improve the surface properties of machine parts [9-11].

Stainless steels have good corrosion resistance due to the formation of hightly coherent, adherent, insulating and renewable chromium oxide film on the surface on the order of only a few atom layers in thick- 
ness. Therefore, they are used in a wide range of goods such as implant material, furniture, automotive trims and cutlery where both aesthetic appearance and corrosion resistance are important design criteria [12-15]. The main objective of this study was to investigate the effect of the boriding process on wear behavior of borided AISI 310 steel. Structural, Daimler-Benz adhesion test and tribological properties were investigated using optical microscopy, XRD, SEM, EDS, microhardness tests and a ball-on-disc tribotester.

\section{MATERIALS AND METHODS}

The AISI 310 stainless steel essentially contained 0.25 wt.\% C, 0.85 wt.\% Mn, 25.0 wt.\% Cr, 19.50 wt.\% Ni and $1.50 \mathrm{wt} . \% \mathrm{Si}$. The test specimens were cut into $\varnothing 25 \times 10 \mathrm{~mm}$ dimensions, ground up to $1000 \mathrm{G}$ and polished using diamond solution. The boriding thermochemical treatment was carried out in a solid medium containing an Ekabor-II powder mixture placed in an electrical resistance furnace operated at the temperature of 1123 and $1323 \mathrm{~K}$ for 2 and $6 \mathrm{~h}$ under atmospheric pressure. Following the completion of the boriding process, test specimens were removed from the/solution, put into a stainless steel container and allowed to cool down in still air. The microstructures of the polished and etched cross-sections of the specimens were observed under a Nikon MA100 optical microscope. The presence of borides formed in the coating layer was confirmed by means of X-ray diffraction equipment (Shimadzu XRD 6000) using $\mathrm{Cu} \mathrm{K} \alpha$ radiation. The microhardness measurements of the boride layer on steel and untreated steel substrate were made on the cross-sections using a Shimadzu HMV-2 Vickers indenter with a $100 \mathrm{~g}$ load.

The Daimler-Benz Rockwell-C adhesion test was used to assess the adhesion of the boride layers. The well-known Rockwell-C indentation test is prescribed by the VDI 3198 norm, as a destructive quality test for coated compounds [16-18]. The principle of this method is presented in the upper right part of Figure 1. A load of $1471 \mathrm{~N}$ was applied to cause coating damage adjacent to the boundary of the indentation. Three indentations were conducted for each specimen and scanning electron microscopy was employed to evaluate the test.
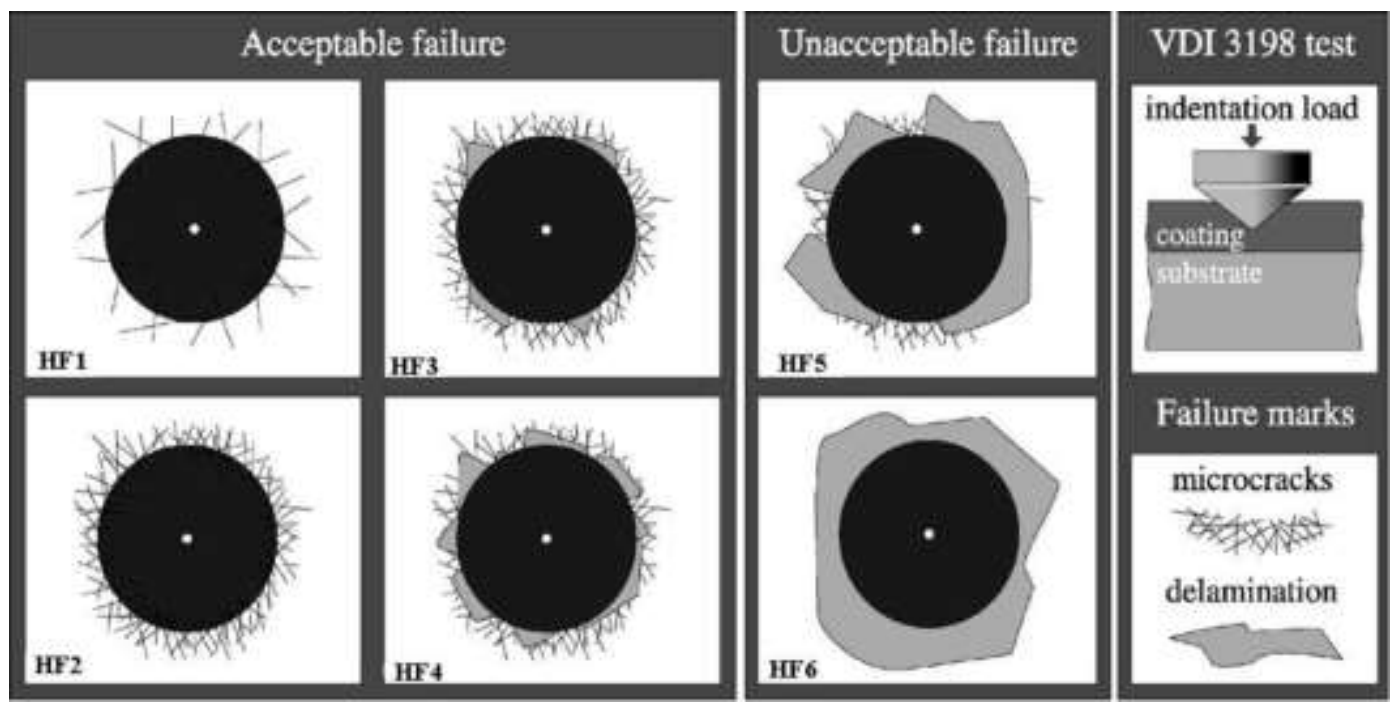

Figure 1: The principle of the VDI 3198 indentation test.

To perform friction and wear of borided samples, a ball-on-disc test (ASTM G99-05) device was used. In this equipment, the bottom part is movable and the top pin or ball stationary. In the present study, the bottom movable flat surface was the borided steel and upper fixed surface was the WC-Co ball with a diameter of $8 \mathrm{~mm}$. The wear experiments were carried out in a ball-disc arrangement under a dry friction condition at room temperature with an applied load of $10 \mathrm{~N}$ and with sliding speeds of $0.3 \mathrm{~m} / \mathrm{s}$ at a sliding distance of $1000 \mathrm{~m}$. The maximum compressive contact pressure in the central point of the contact area was calculated from Hertzian equation [19, 20]. Young's modulus and Poisson's ratio of WC-Co ball are 650 GPa and 0.26. According to the Hertzian equation, maximum contact pressures of $2139 \mathrm{MPa}$ were obtained at normal load of $10 \mathrm{~N}$. Before and after each wear test, each sample and abrasion element was cleaned with alcohol. After the test, the wear volumes of the samples were quantified by multiplying the cross-sectional areas of the wear 
by the width of the wear track obtained from the Taylor-Hobson Rugosimeter Surtronic 25 device. The wear rate was calculated with the equation:

$$
\mathrm{Wk}=\frac{W v}{M \cdot S} m m^{3} / \mathrm{Nm}
$$

Where $\mathrm{Wk}$ is the wear rate, $\mathrm{Wv}$ the worn volume, $\mathrm{M}$ the applied load and $\mathrm{S}$ is the sliding distance. Friction coefficients depending on sliding distance were obtained through a friction coefficient program. Surface profiles of the wear tracks on the samples and surface roughness were measured by a Taylor-Hobson Rugosimeter Surtronic 25. Worn surfaces were investigated by scanning electron microscopy (SEM) and energy-dispersive X-ray spectroscopy (EDS).

\section{RESULTS AND DISCUSSION}

The cross-section of the optical micrographs of the borided AISI 310 steel at the temperature of $1123 \mathrm{~K}$ and $1323 \mathrm{~K}$ for 2 and $6 \mathrm{~h}$ is shown in Figure 2. The borides formed in AISI 310 steel have a smooth and regular morphology. It was found that the coating/matrix interface and matrix could be significantly distinguished and the boride layers have a non-columnar structure. Depending on the boriding time and temperature the boride layer thickness on the surface of the AISI 310 steel ranged from $7.82 \mu \mathrm{m}$ and $56.74 \mu \mathrm{m}$ in Figure 2 .

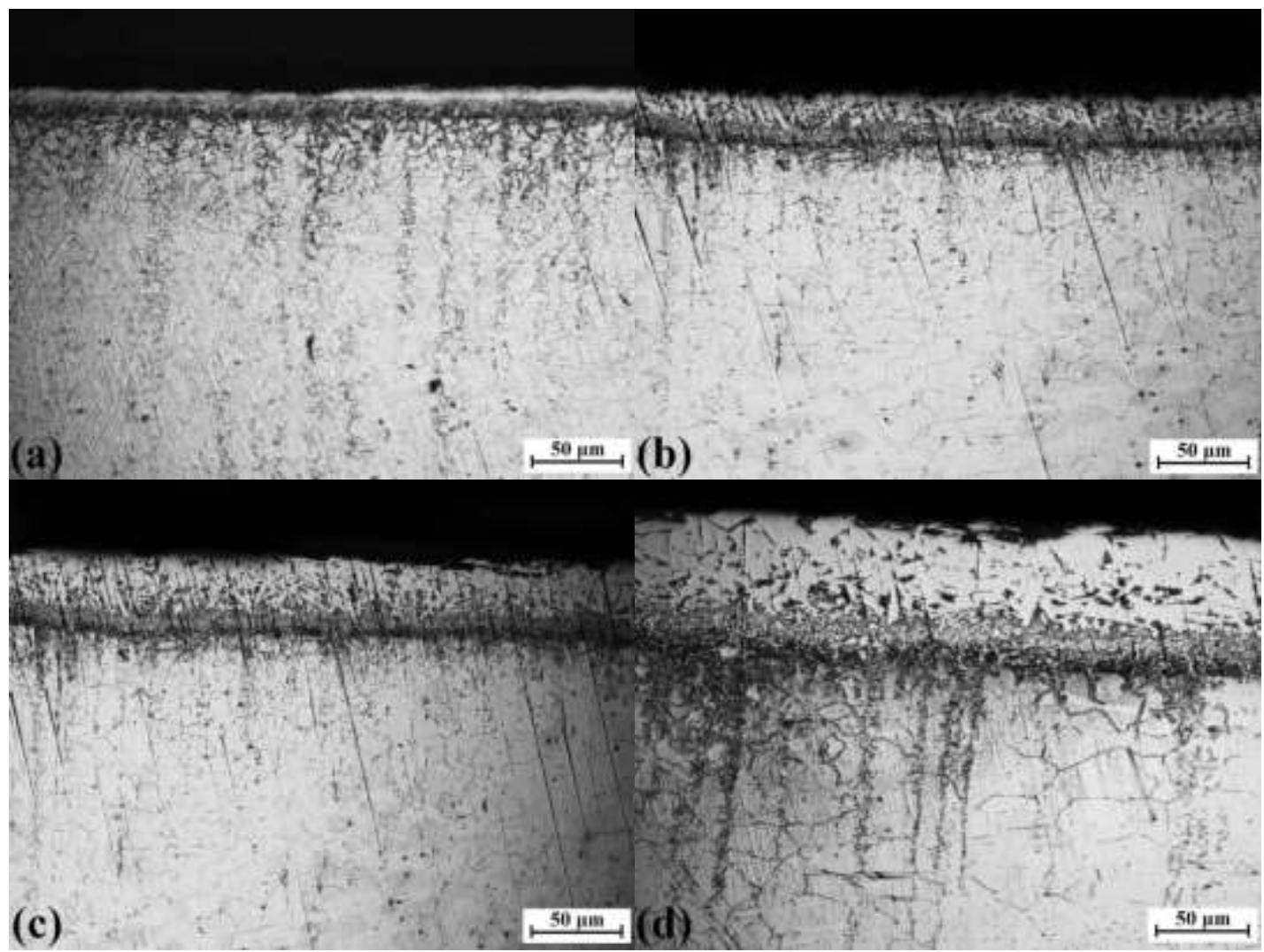

Figure 2: The cross-section of borided AISI 310 steel; a) $1123 \mathrm{~K}-2 \mathrm{~h}, \mathrm{~b}) 1123 \mathrm{~K}-6 \mathrm{~h}, \mathrm{c}) 1323 \mathrm{~K}-2 \mathrm{~h}$, d) $1323 \mathrm{~K}-6 \mathrm{~h}$.

The Figure 3 shows the XRD pattern obtained at the surface of borided AISI 310 steel at $1123 \mathrm{~K}$ and $1323 \mathrm{~K}$ for the treatment times of 2 and $6 \mathrm{~h}$. 


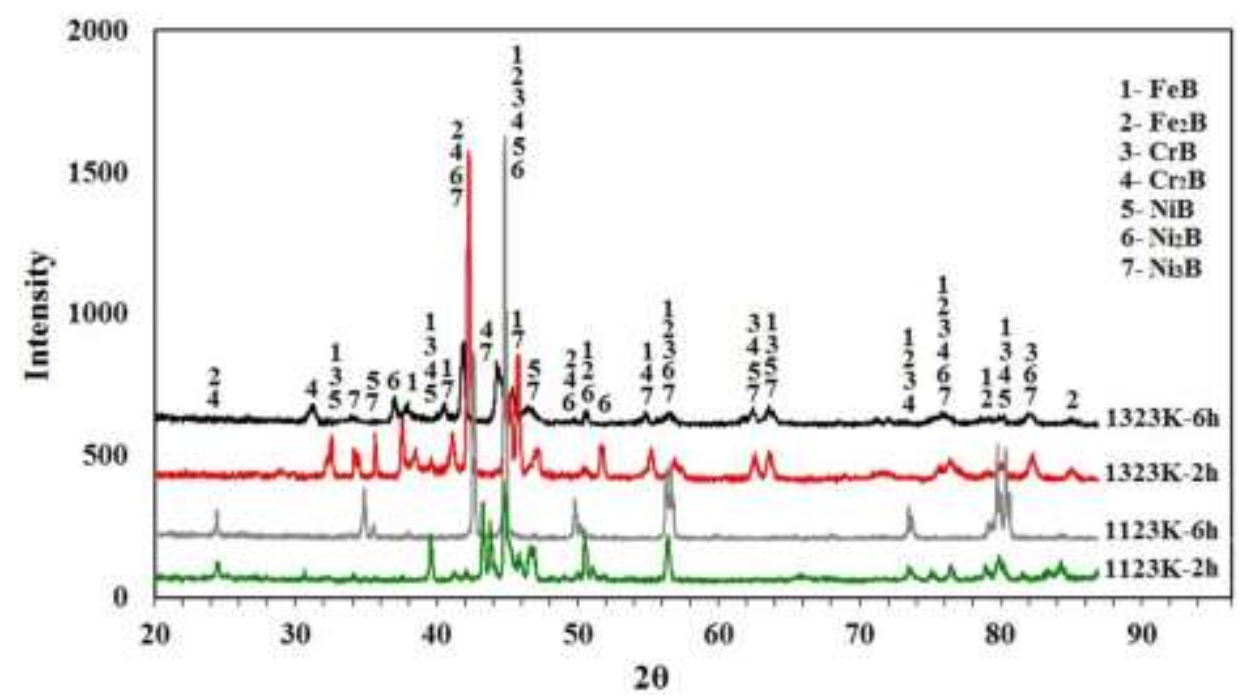

Figure 3: X-ray diffraction patterns of borided AISI 310 steel

XRD patterns show that the boride layer consists of borides such as $\mathrm{MB}$ and $\mathrm{M}_{2} \mathrm{~B}(\mathrm{M}=\mathrm{Metal} ; \mathrm{Fe}, \mathrm{Cr}$, $\mathrm{Ni}$ ). XRD results showed that boride layers formed on the AISI 310 stainless steel contained $\mathrm{FeB}, \mathrm{Fe}_{2} \mathrm{~B}, \mathrm{CrB}$, $\mathrm{Cr}_{2} \mathrm{~B}, \mathrm{NiB}, \mathrm{Ni}_{2} \mathrm{~B}, \mathrm{Ni}_{3} \mathrm{~B}$ phases. With increasing time and temperature, the $\mathrm{Fe}_{2} \mathrm{~B}$ phase content decreases and $\mathrm{FeB}, \mathrm{CrB}, \mathrm{NiB}$ phase content increases, for AISI 310 steel. The boride layers mainly consist of a double intermetallic phase $\left(\mathrm{FeB}\right.$ and $\left.\mathrm{Fe}_{2} \mathrm{~B}\right)$ as a result of the diffusion of boron atoms from the boriding compound to the metallic lattice, with respect to the holding time.

Micro-hardness measurements were carried out from the surface to the interior along a line in order to see the variations in the boride layer hardness, transition zone and matrix, respectively (Figure 4). The micro-hardness of the boride layer was measured at 10 different locations at the same distance from the surface and the average value was taken as the hardness. The boride layer hardness of the sample borided at $1323 \mathrm{~K}$ for $6 \mathrm{~h}$ was found to be $2284 \mathrm{HV}_{0,1}, 1323 \mathrm{~K}$ for $2 \mathrm{~h}$ was $1972 \mathrm{HV}_{0,1}, 1123 \mathrm{~K}$ for $6 \mathrm{~h}$ was $1785 \mathrm{HV}_{0,1}$ and $1123 \mathrm{~K}$ for $2 \mathrm{~h}$ was $1658 \mathrm{HV}_{0,1}$. On the other hand, Vickers hardness values were $276 \mathrm{HV}_{0,1}$, for the untreated AISI 310 steel. Figure 4 show that increasing the boriding temperature and treatment time increases the boride layer hardness. When the hardness of the boride layer is compared with the matrix, boride layer hardness is approximately eight times greater than that of the matrix (1323K for $6 \mathrm{~h})$.

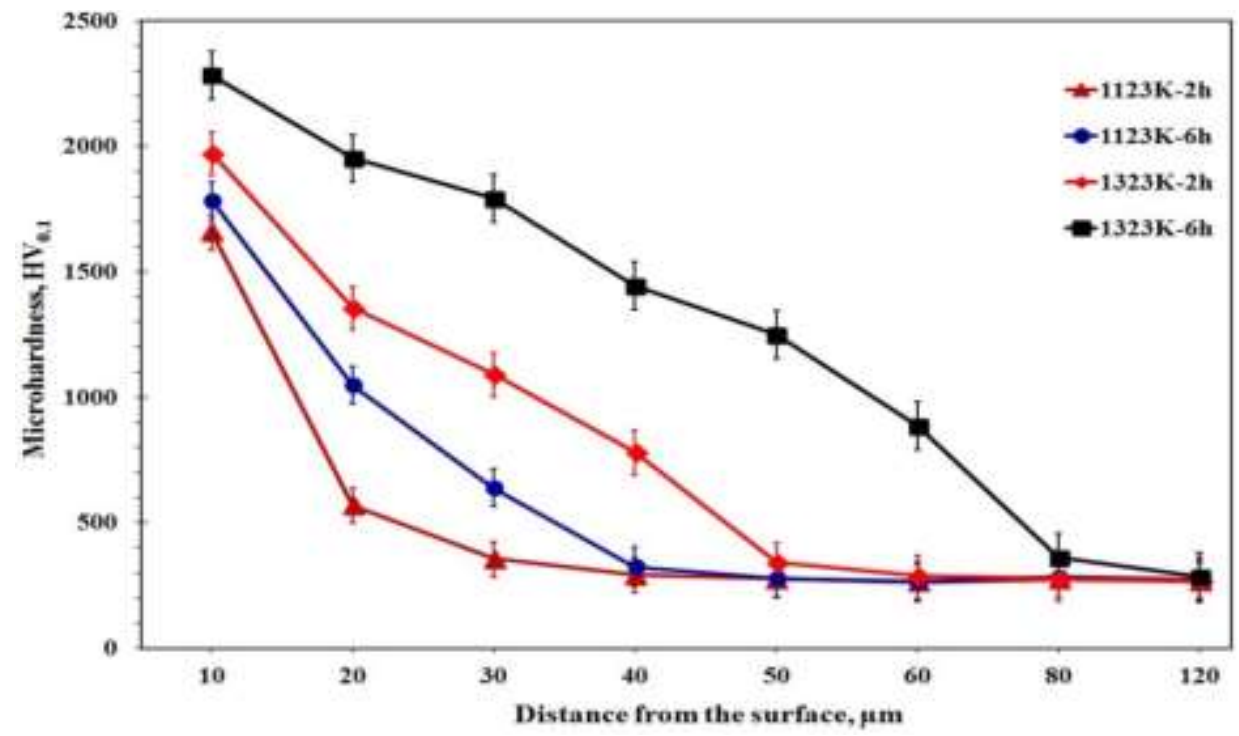

Figure 4: The variation of hardness depth in the borided AISI 310 steels

A standard Rockwell-C hardness tester was employed in this study. The damage to the boride layer was compared with the adhesion strength quality maps HF1-HF6. In general, the adhesion strength quality HF1-HF4 defines sufficient adhesion, whereas HF5 and HF6 represent insufficient adhesion [17]. 

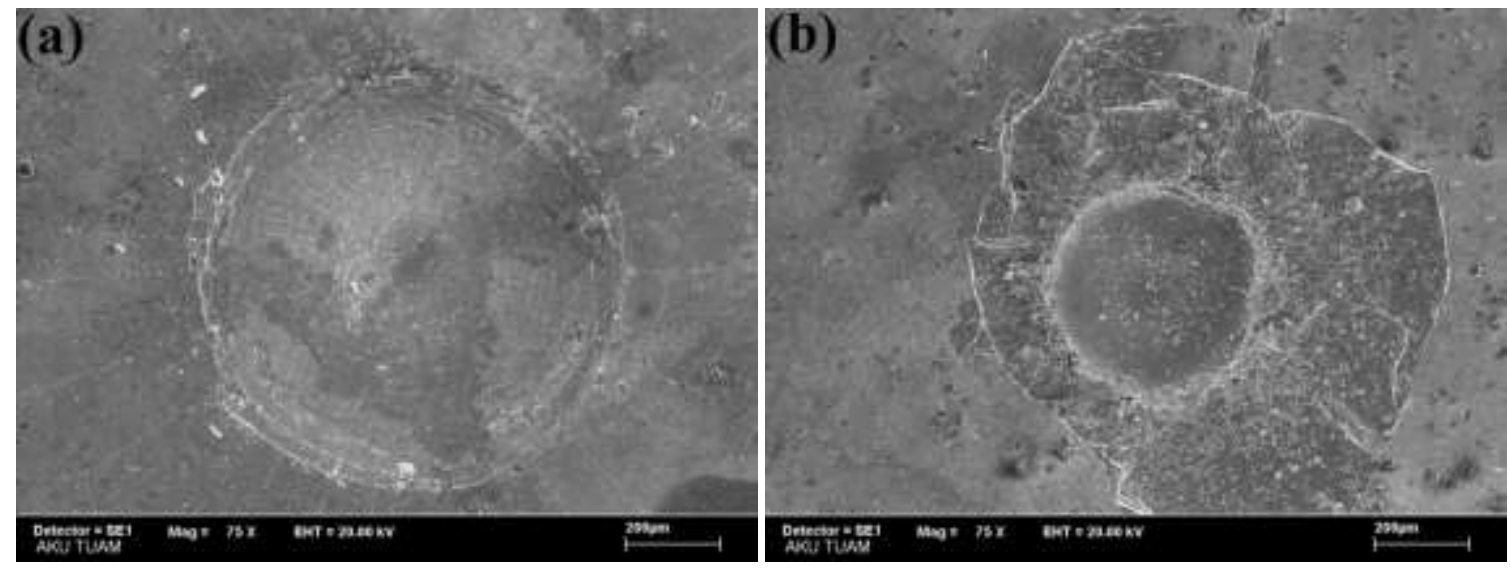

Figure 5: SEM micrograph of VDI adhesion test on AISI 310 steel; a) $1123 \mathrm{~K}-2 \mathrm{~h}$, b) $11323 \mathrm{~K}-6 \mathrm{~h}$

SEM micrographs of the indentation craters for samples borided at $1123 \mathrm{~K}$ for $2 \mathrm{~h}$ and $1323 \mathrm{~K}$ for $6 \mathrm{~h}$ are shown in Figure 5. There were radial cracks at the perimeter of the indentation craters without flaking and the adhesion of the boride layer on the sample borided at $1123 \mathrm{~K}$ for $2 \mathrm{~h}$ was sufficient (Fig.5a). However, radial crack and partial flaking at the perimeter of indentation craters was found on the sample borided at $1323 \mathrm{~K}$ for $6 \mathrm{~h}$ (Fig.5b). The adhesion strength quality of these boride layers are related to HF1 and HF6 (Fig. 1). These results show that adhesion of boride layers on both samples is sufficient according to the adhesion strength quality maps.

Table 1 shows that increasing the boriding temperature and treatment time increases the surface roughness values. It was observed that in AISI 310 steel surface roughness values increased with the boriding treatment. Gunes [21], Ulker [22], and Sahin [23] solid borided steels and reported that surface roughness values increased with an increase in the boriding temperature. On the other hand, the friction coefficients of the unborided and borided stainless steel varied from 0.35 to 0.67 , as can be seen in Figure 6 . With the boriding treatment, a slight reduction was observed in the friction coefficients of the borided steels.

Table1: Surface roughness values of the unborided and borided AISI 310 steel

\begin{tabular}{|c|c|c|c|c|}
\hline \multicolumn{5}{|c|}{ Surface roughness values, Ra $(\boldsymbol{\mu m})$} \\
\hline \multirow{2}{*}{ Unborided } & \multicolumn{4}{|c|}{ Borided } \\
\cline { 2 - 5 } & $\mathbf{1 1 2 3 K}-\mathbf{2} \mathbf{~ h}$ & $\mathbf{1 1 2 3 K}-\mathbf{6 ~ h}$ & $\mathbf{1 3 2 3 K}-\mathbf{2} \mathbf{~ h}$ & $\mathbf{1 3 2 3 K}-\mathbf{6} \mathbf{~ h}$ \\
\hline $0.11 \pm 0.008$ & $0.36 \pm 0.015$ & $0.41 \pm 0.034$ & $0.47 \pm 0.028$ & $0.54 \pm 0.042$ \\
\hline
\end{tabular}




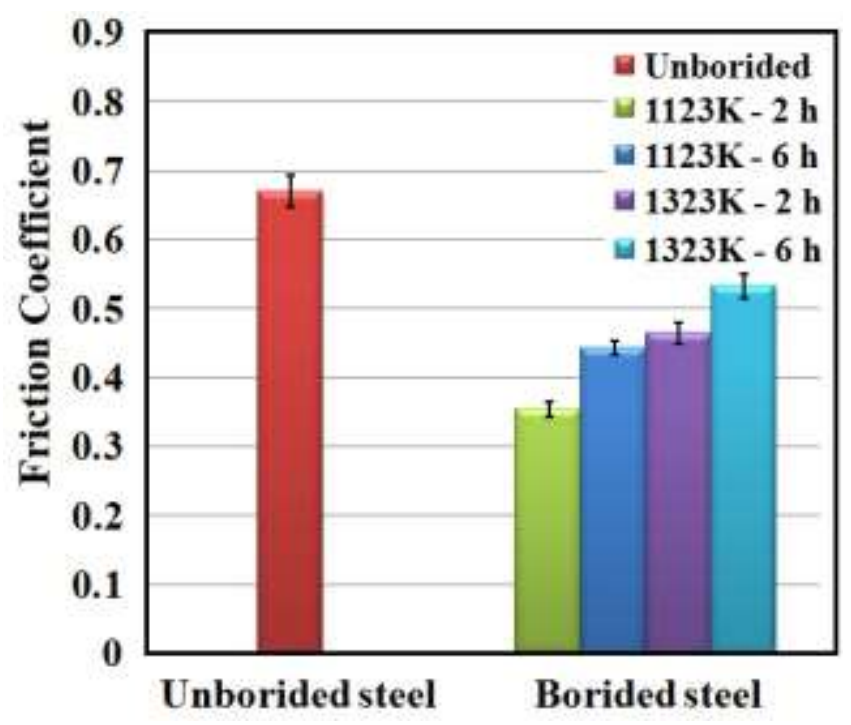

Figure 6: The Friction coefficient of unborided and borided AISI 310 steel.

Figure 7 shows the wear rate of the unborided and borided AISI 310 steel. Reductions in the wear rates of the borided steels were observed according to the unborided steels. Due to the hardness of the FeB and $\mathrm{CrB}$ phases, the steel showed more resistance to wear. With the increase in temperature in the boriding process, the $\mathrm{FeB}$ and $\mathrm{CrB}$ phases increased more than that of the $\mathrm{Fe}_{2} \mathrm{~B}$ and $\mathrm{Cr}_{2} \mathrm{~B}$ phases, and this, at the same time, led to an increase in the surface roughness [4,5,8, 24]. Ozbek and Bindal [4] borided AISI W4 steel by Ekabor powders and found that higher boriding temperatures resulted in higher hardnesses due to the formation of the harder FeB phase. This is due to the fact that the hardness and thickness of the borided layers were higher. Borided steels are extremely resistant to abrasion on account of their great hardness $[5,8,15,25]$.

It is observed that in all borided steels, a rather low level of wear occurred (Fig. 7). The lowest wear rate was obtained in the AISI 310 steel borided at $1323 \mathrm{~K}$ for 6 hours, while the highest wear rate was obtained in the unborided AISI 310 steel. The wear test results indicated that the wear resistance of borided steels increased considerably with the boriding treatment and time. It is well known that the hardness of the boride layer plays an important role in the improvement of wear resistance. As shown in Fig. 4 and Fig. 7, the relationship between the surface microhardness and the wear resistance of the borided samples also confirms that the wear resistance was improved with the hardness increasing. This is in agreement with the reports of previous studies [21-25]. The borided samples showed wear resistance for a long period of time due to the fact that the boride layer had a higher hardness and low friction coefficient $[26,27]$. When the wear rate of the borided steel is compared with the unborided steel, the wear rate of the borided steels is approximately four times lower than that of the unborided steels. The wear rate of the unborided sample was $71.42 \times 10^{-6}$, however this value dropped to $4.57 \times 10^{-5}(1323 \mathrm{~K}-6 \mathrm{~h})$ as a result of the boriding process. 


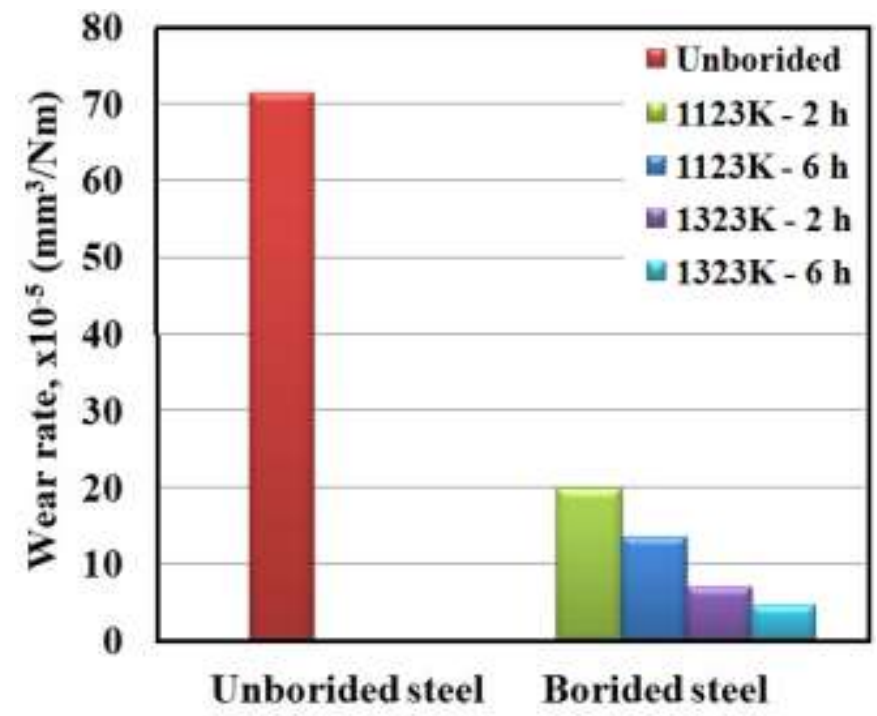

Figure 7: The wear rate of unborided and borided AISI 310 steel.

The SEM micrographs of the worn surfaces of the unborided and borided AISI 310 steel are illustrated in Figs. 8 and 9. Figure 8a shows the SEM micrographs of the wear surfaces of the unborided AISI 310 steel. The worn surface of the unborided steel was rougher and coarser and wear debris particles were present.
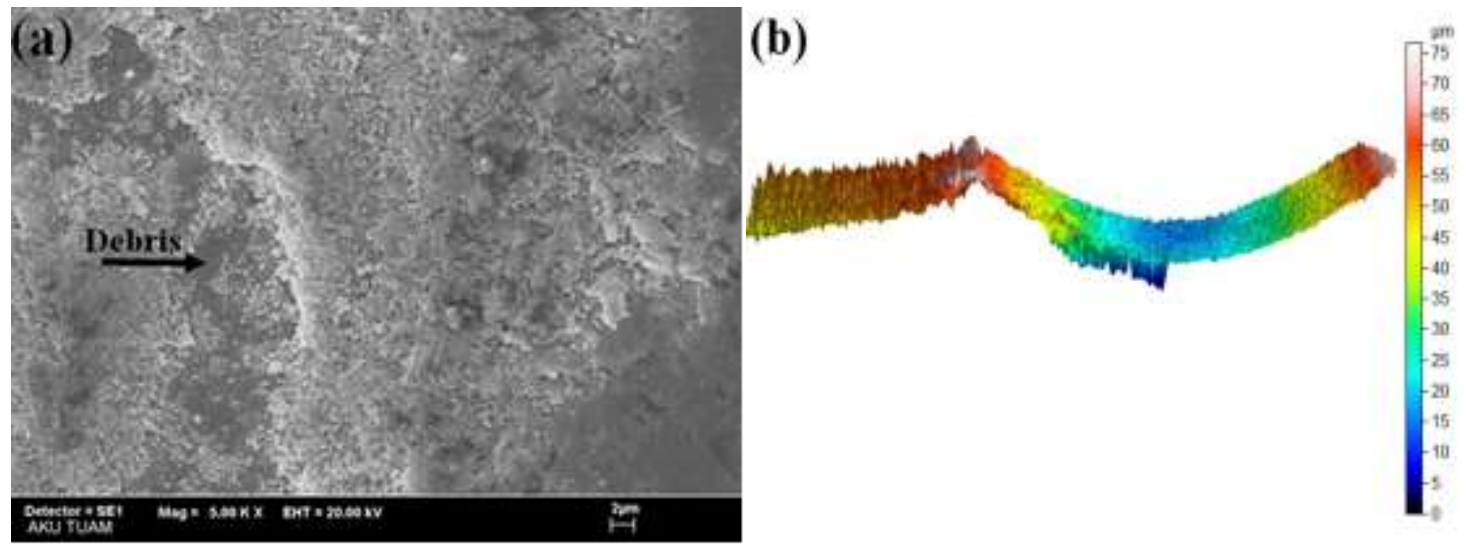

Figure 8: The SEM micrograph and cross-sectional surface of the worn-out surfaces of the unborided AISI 310 steel; a) unborided, b) cross-sectional surface (CS) 

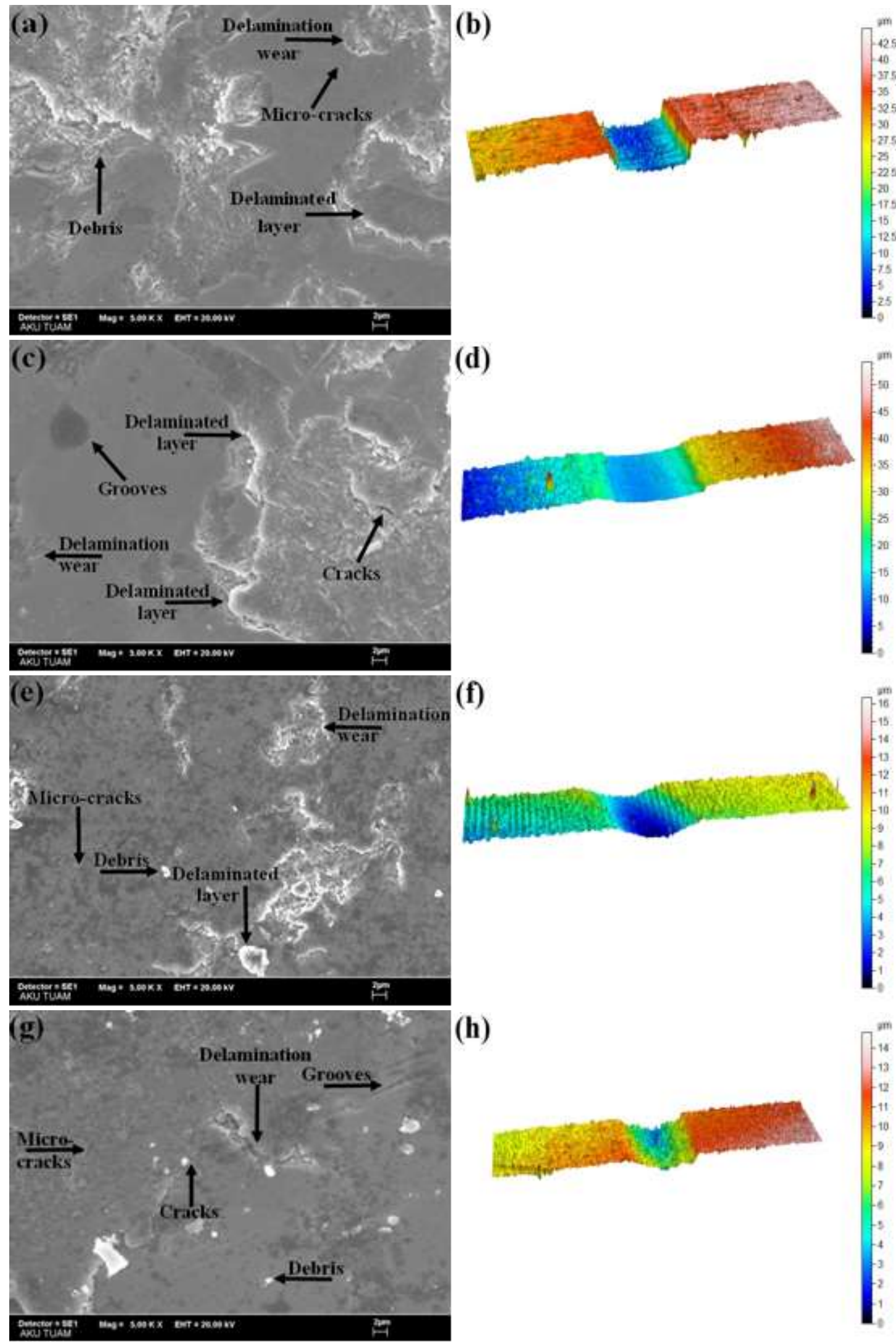

Figure 9: The SEM micrographs and cross-sectional surface of the worn-out surfaces of the borided AISI 310 steel; a) $1123 \mathrm{~K}-2 \mathrm{~h}, \mathrm{~b}) 1123 \mathrm{~K}-2 \mathrm{~h} \mathrm{CS}$, c) $1123 \mathrm{~K}-6 \mathrm{~h}, \mathrm{~d}) 1123 \mathrm{~K}-6 \mathrm{~h} \mathrm{CS}, \mathrm{e}) 1323 \mathrm{~K}-2 \mathrm{~h}$, f) $1323 \mathrm{~K}-2 \mathrm{~h} \mathrm{CS}, \mathrm{g}) 1323 \mathrm{~K}-6 \mathrm{~h}$, h) $1323 \mathrm{~K}-6 \mathrm{~h} \mathrm{CS}$. 


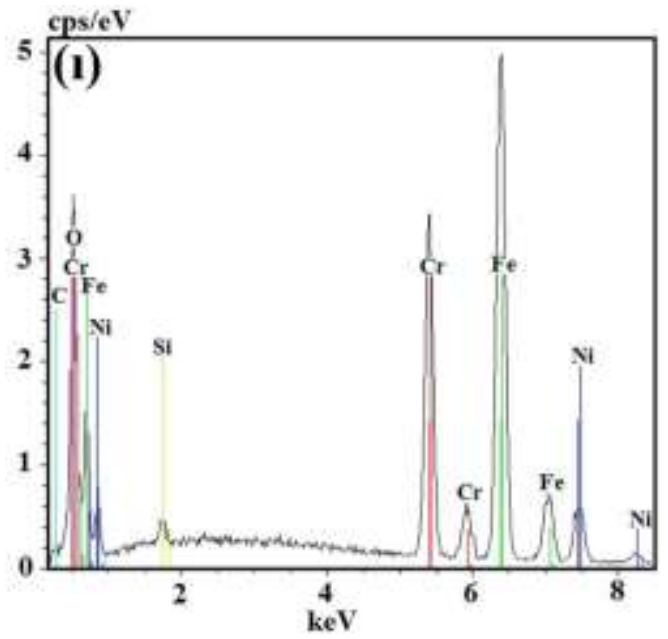

Figure 10: The EDS analysis obtained from Figure 9g.

The wear region of the borided steel, debris, delamination wear, surface grooves and cracks on the surface can be observed (Fig. 9). There were micro-cracks, abrasive particles and small holes on the worn surface of the boride coatings. In the wear region of borided AISI 310 steel, there were cavities probably formed as a result of layer fatigue and cracks concluded in delaminating wear. Figure 9 shows the wear surfaces, and the cross-sectional surface (CS) of the wear mark obtained from the wear region by analyzing multiple profilometry surface line scans using a Nanovea ST-400 non-contact optical profiler. It was observed that the depth and width of the wear trace on the surfaces of the samples decreased with an increase in the boriding temperature and time. Figure 10 shows the EDS analysis obtained from Figure 9g. Fe-based oxide layers formed as a result of the wear test. The spallation of the oxide layers in the sliding direction and their orientation extending along the wear track were identified. When the SEM image of the worn surfaces of the unborided sample is examined, it can be seen that the wear marks in Fig. 8b are larger and deeper.

\section{CONCLUSIONS}

In this study, wear behavior and some mechanical properties of borides on the surface of borided AISI 310 stainless steel were investigated. Some of the conclusions can be drawn as follows.

- Boride types formed on the surface of the steel have a smooth morphology.

- The boride layer thickness on the surface of the AISI 310 steel was obtained, depending on the boriding time and temperature, 7.82-56.74 $\mu \mathrm{m}$.

- The multiphase boride coatings that were thermochemically grown on the AISI 310 stainless steel was constituted by the $\mathrm{FeB}, \mathrm{Fe}_{2} \mathrm{~B}, \mathrm{CrB}, \mathrm{Cr}_{2} \mathrm{~B}, \mathrm{NiB}, \mathrm{Ni}_{2} \mathrm{~B}$ and $\mathrm{Ni}_{3} \mathrm{~B}$ phases.

- The surface hardness of the borided steel was in the range of $1658-2284 \mathrm{HV}_{0,1}$, while for the untreated steel substrate it was $276 \mathrm{HV}_{0,1}$.

- Surface roughness of the coating increased from approximately 0.11 to $0.54 \mu \mathrm{m}$ with respect to time of boriding.

- Coefficient of friction values (between 0.35 and 0.53 ) for the boriding samples were lower than the coefficient of friction values $(0.67)$ of the unborided steel sample.

- The wear resistance of the borided steel strongly decreased with increasing temperature and borided samples exhibited considerably lower wear rate compared with unborided sample.

- The wear rate of the unborided sample was $71.42 \times 10^{-6}$, however this value dropped to $4.57 \times 10^{-5}$ as a result of the boriding process.

- The wear rate of the borided steel was found to be approximately seven times lower the wear rate of the unborided steel.

\section{BIBLIOGRAPHY}

[1] KEDDAM, M., "Simulation of the growth kinetics of FeB and Fe2B phases on the AISI M2 borided steel: Effect of the paste thickness", International Journal of Materials Research, v. 100, pp. 901-905, 2009. 
[2] GUNES, I., "Kinetics of borided gear steels", Sadhana, v. 38, pp. 527-541, 2013.

[3] ERDOGAN, M., GUNES, I., “Corrosion Behavior and Microstructure of Borided Tool Steel”, Matéria, v.20, pp. 523-529, 2015

[4] OZBEK, I., BINDAL, C., "Mechanical properties of boronized AISI W4 steel”, Surface and Coatings Technology, v. 154, pp. 14-20, 2002.

[5] GUNES, I., "Tribological behavior and characterization of borided cold-work tool steel", Materials and Technology/Materiali in Tehnologije, v. 48, pp. 765-769, 2014.

[6] LESNIEWSKI, T., KRAWIEC, S., "The effect of ball hardness on four-ball wear test results", Wear, v. 264, pp. 662-670, 2008.

[7] GUNES, I., UYGUNOĞLU, T., ERGEN, A., KISIKÇILAR, T., AKSOY, E., "Investigation of Wear Behavior of Borided DIN 20MoCr4 Steel", Journal of Science and Engineering, v. 2, pp. 53-58, 2015.

[8] TABUR, M., IZCILER, M., GUL, F., KARACAN, I., "Abrasive wear behavior of boronized AISI 8620 steel”, Wear, v. 266, pp. 1106-1112, 2009.

[9] MINDIVANA, H., "Effects of Combined Diffusion Treatments on the Wear Behaviour of Hardox 400 Steel”, Procedia Engineering, v. 68, pp. 710-715, 2013.

[10] MU, D., SHEN, B., ZHAO, X., "Effects of Boronizing on Mechanical and Dry-Sliding Wear Properties of CoCrMo Alloy", Materials and Desing, v. 31, pp. 3933-3936, 2010.

[11] GUNES, I., "Tribological properties and characterisation of plasma paste borided AISI 5120 steel", Journal of the Balkan Tribological Association, v. 20, pp. 351-361, 2014.

[12] OZDEMIR, O., OMAR, M. A., USTA, M., et al., "An investigation on boriding kinetics of AISI 316 stainless steel,"Vacuum, v. 83, pp. 175-179, 2009.

[13] OZBEK, I., KONDUK, B. A., BINDAL, C., et al., "Characterization of borided AISI 316L stainless steel implant", Vacuum, v. 65, pp. 521-525, 2002.

[14] GUNEN, A., GOK, M.S., ERDOGAN, A., et al., "Investigation of Microabrasion Wear Behavior of Boronized Stainless Steel with Nanoboron Powders", Tribology Transactions, v. 56, n.3, pp. 400-409, 2013.

[15] GUNEN, A., ULUTAN, M., GOK, M.S., et al., "Friction and wear behaviour of borided aisi 304 stainless steel with nano particle and micro particle size of boriding agents," Journal of the Balkan Tribological Association, v.20, pp. 362-379, 2014.

[16] Verein Deutscher Ingenieure Normen, VDI 3198, VDI-Verlag, Dusseldorf, 1991.

[17] VIDAKIS, N., ANTONIADIS, A., BILALIS, N., "The VDI 3198 indentation test evaluation of 225 a reliable qualitative control for layered compounds", J. Mater. Process Technol, v. 226, pp. 143-144:481485, 2003.

[18] GUNES, I., KAYALI, Y., "Investigation of mechanical properties of borided Nickel 201 alloy", Materials and Design, v. 53, pp. 577-580, 2014.

[19] JOHNSON, K.L. Contact Mechanics, Cambridge, Cambridge University Press, 1985.

[20] WILLIAMS, J.A., Engineering Tribology, New York, Oxford University Press, 1996.

[21] GUNES, I, TAKTAK, S., "Surface characterization of pack and plasma paste boronized of $21 \mathrm{NiCrMo} 2$ steel", Journal of the Faculty of Engineering and Architecture of Gazi University, v. 27, pp. 99-108, 2012.

[22] ULKER, S., GUNES, I., TAKTAK, S., "Investigation of tribological behaviour of plasma paste boronized of AISI 8620, 52100 and 440C steels", Indian Journal of Engineering \& Materials Sciences, v. 18, pp. 370-376, 2011.

[23] SAHIN, S., "Effects of boronizing process on the surface roughness and dimensions of AISI 1020, AISI 1040 and AISI 2714", J. Mater. Process. Tech., v. 209, pp. 1736-1741, 2009.

[23] MU, D., SHEN, B., ZHAO, X., "Effects of boronizing on mechanical and dry-sliding wear properties of CoCrMo alloy", Materials and Design, v. 31, pp. 3933-3936, 2010.

[24] GUNES, I., "Investigation of Tribological Properties and Characterization of Borided AISI 420 and AISI 5120 Steels", Transactions of the Indian Institute of Metals, v. 67, pp. 359-365, 2014. 
[25] HARDELL, J., KASSFELDT, E., PRAKASH, B., "Friction and wear behaviour of high strength boron steel at elevated temperatures of up to $800^{\circ}{ }^{\circ}$ ", Wear, v. 264, pp. 788-799, 2008.

[26] SHADRICHEV, E.V., RUMYANTSEV, S.I., "Wear kinetics of a two phase boride layer", Metal Science and Heat Treatment (USSR), Met. Sci. Heat Treat., v.24, pp. 495-498, 1982.

[27] ULUTAN, M., YILDIRIM, M.M., CELIK, O.N., et al., "Tribological properties of borided AISI 4140 steel with the powder pack-boriding method", Tribol. Lett., v.38, pp. 231-239, 2010. 